\title{
Ecological and Epidemiological Aspects of West Nile Virus in Ukraine
}

\author{
Alla Yushchenko ${ }^{1 *}$, Jason Farlow ${ }^{2}$ and Zinaida Klestova ${ }^{1}$ \\ ${ }^{1}$ State Scientific-Control Institute of Biotechnology and Strains of Microorganisms \\ (SSCIBSM) Kyiv, Ukraine \\ ${ }^{2}$ Farlow Scientific Consulting, Lewiston, Utah, USA \\ *Corresponding Author: Alla Yushchenko, State Scientific-Control Institute of \\ Biotechnology and Strains of Microorganisms (SSCIBSM) Kyiv, Ukraine.
}

\author{
Received: March 30, 2020 \\ Published: April 14, 2020 \\ (C) All rights are reserved by Alla Yushchenko \\ ., et al.
}

\begin{abstract}
West Nile fever (WNF) is a viral mosquito-transmitted disease caused by West Nile virus (WNV), a member of the Flaviviridae family. WNV infects an extremely wide range of susceptible hosts and is capable of replicating in mammals, birds, reptiles and amphibians. The enzootic lifecycle of WNV consists of cycling between mosquitoes and birds and sporadic spillover results in disease in horses and humans. Rare and severe neuroinvasive disease in humans and horses occurs. The epidemic significance of WNV infection is illustrated by its worldwide distribution, variable clinical prognosis of disease, and lack of therapeutic options. In Ukraine, 14 enzootic territories have been identified. While climate conditions, water sources and a large number of avian migratory routes create optimal conditions for the pathogen circulation in the country, the epidemiological status of WNV in Ukraine is poorly defined. Annual introduction of WNV to Ukraine likely occurs via seasonal migratory bird routes that exist regionally between Ukraine and neighboring European countries. The genotype of historical avian Ukrainian isolate exhibits the Lineage 2 genotype, however, only limited WNV genome sequences from Ukraine are available. Enhanced viral surveillance and serologic diagnosis of WNF in Ukraine is warranted and remains an essential measure for a clear understanding of the current epidemic situation and the prediction of possible WNV outbreaks in the future.
\end{abstract}

Keywords: West Nile Virus; Ukraine; Transmission; Vectors; Birds; Enzootic Cycle; Migration

\section{Abbreviations}

NF: West Nile Fever; WNV: West Nile Virus; CNS: Central Nervous System; EU: European Union

\section{Introduction}

WNV is the causative agent of WNF and West Nile encephalomyelitis (WNE) in humans and horses [1]. Horses and humans are dead-end hosts in the WNF enzootic cycle and experience severe febrile neuroinvasive illness [2]. There are three forms of clinical symptoms that can be differentiated based on clinical manifestation. Approximately $85 \%$ of all WNF cases are asymptomatic whereas 13 - 20\% present with flu-like symptoms, and only $2 \%$ of total cases are characterized by a severe neuroinvasive course. WNV encephalitis in humans and mice, is characterized by pronounced CNS inflammation in the parenchyma and perivascular space. Risk factors for acute WNV infection include immunosuppression and increased age however the requisites for this interaction remain largely unknown $[3,4]$. WNV is commonly transmitted to humans through the bite of infected multiple competent species of mosquitos with some transmission reported by soft and hard ticks.

\section{History and geography of disease}

WNV was first isolated in 1937 in Uganda from a patient with a febrile illness and later recognized as the most common Flavivirus found in all continents except Antarctica. In European countries, the first case of encephalitis caused by the WNV was described in 1960s in France in the Camargue region [5]. Up to the mid-1990s, WNV had circulated in Central Europe though it posed no particular threat to human health as it caused only sporadic cases of disease. The first significant WNF outbreak occurred in 1996 in Romania and spread to 14 administrative units in the Danube Valley and Bucharest [6]. Within four years, the presence of specific antibodies to WNF virus confirmed infection in 835 patients with neurological symptoms [7], with a mortality rate of $10 \%$ [6]. The geographical distribution of WNF cases among European countries is variable. While in some countries no cases among people or animals have been reported, countries including Austria, Czech Republic, Hun- 
gary, Bulgaria, Greece, Italy, France, Spain and Portugal are recognized as endemic [8]. As of 4 December 2019, European Union (EU) Member States and EU neighboring countries reported 463 human infections in 2019. EU Member States reported 410 cases: Greece $(\mathrm{N}=223)$, Romania $(\mathrm{N}=66)$, Italy $(\mathrm{N}=53)$, Hungary $(\mathrm{N}=$ 36), Cyprus $(\mathrm{N}=16)$, Bulgaria $(\mathrm{N}=5)$, Austria $(\mathrm{N}=4)$, Germany $(\mathrm{N}=4)$, France $(\mathrm{N}=2)$ and Slovakia $(\mathrm{N}=1)$ (https://www.ecdc. europa.eu/en/news-events/epidemiological-update-west-nile-virus-transmission-season-europe-2019). EU neighboring countries reported 53 human cases: 27 in Serbia, 10 in Israel, 10 in Turkey and 6 in North Macedonia. In the same time period, 50 deaths due to WNV infections have been reported.

In Ukraine, the first reports of the WNV presence in humans and birds appeared in the 1970s. In 1974, neuroinvasive cases were described in humans, as well as specific antibodies were detected in wild and farm animals in the South East USSR. In 1985, 38 cases were reported in Transcarpathian region, 16 of which were neuroinvasive [9]. At the same time, virus from blood samples and internal organs of wild birds (Corvus frugilegus) were isolated in the north-western Black Sea region [10]. To date, the existence of 14 enzootic territories of West Nile fever has been identified in Ukraine (Figure 3). Climate conditions, water sources and a large number of birds migratory routes create optimal conditions for the pathogen circulation in the country. However, the epidemiological status of Ukraine regarding to WNF has not been established yet [2].

\section{Ecology and epidemiology of WNV}

The ecological dynamics of West Nile fever is complex with multiple interrelated biotic and abiotic factors that may impact the epidemiology and transmission of disease. Biotic factors include host susceptibility and immunity, genetic features, vector competence, vectors' food preferences and their life cycle. Abiotic factors such as environmental conditions can impact transmission dynamics including biotic factors, such as the density and prevalence of vectors and hosts in a given territory [11].

In Europe, the circulation of the pathogen occurs in persistent natural and anthropogenic centers [8]. Rural areas with a large amount of water resources are an ideal place for nesting, breeding and rearing of migratory birds. Ornithophilic mosquitoes are an integral part of such groups and may support the formation of a stable transmission cycle of WNV in natural locations. Indeed, the spatial relationship between landscape features and wetlands can be traced to the human outbreaks in the Danube Delta in Romania, Volga in Russia and along the Rhine river in France [11].
At present, there is no clear picture of the epidemiological situation amongst the Ukrainian population due to the wide range of clinical symptoms and lack of available diagnostic kits, which complicate the initial diagnosis of the disease. Monitoring of WNF is also complicated by a fact that only $1 \%$ of patients seek medical support (according to WHO). Together, these challenges limit the effective control of West Nile virus in the country, for example, in Zaporizhzhia region the number of cases of WNF reaches up to $11 \%$ of all fever-like diseases [10].

\section{WNV transmission}

WNV has been isolated from 60 mosquito species, among which the Culex genus plays a major role in disease transmission [12]. Moreover, vector competence of Aedes, Anopheles, Culiseta, Coquillettidia, Uranotaenia [13], also soft and Ixodes ticks [14] have been established. It is established that the efficiency of viral transmission is determined by the viremia rate in infection reservoirs [15].

In urban areas, anthropogenic centers of WNF included birds such as crows, pigeons, sparrows, and waterfowl [8]. According to some reports, birds in urban areas could be reservoirs of viruses with a higher genetic diversity than in natural areas [16]. This suggests that anthropogenic factors may play an important role in the transmission and evolution of arboviruses (arthropod-borne viruses) [14]. Elements of urban infrastructure such as sewage system, such as submerged basements create ideal conditions for the propagation of a synanthrope subspecies of the Culex pipiens $f$. molestus mosquito [16]. Key is the fact that Culex pipiens f. molestus females are anthropophilic with no diapause in their life cycle [17] resulting in a lack of seasonality in human blood meal seeking. Thus, WNV is maintained environmentally during the inter-epidemic season, which allows new outbreaks without the re-emergence from other territories.

As a member of Culicidae family, the Culex pipiens mosquito exhibits a complete life cycle that is divided into four stages: egg, larva, pupa and imago (adult). In general, the life cycle of female mosquito lasts approximately 40 days. Once infected, the virus is carried over the duration of its life and can potentially transmit the virus to every vertebrate on which it feeds. Moreover, transovarian transmission occurs in the Culicidae family, thus maintaining the virus vertically within mosquito populations without new introductions by other infected hosts.

Ambient temperature is one of the essential factors that determine the dynamics of the epizootic process, since it directly effects survival of adult mosquitoes, increases the size of mosquito 
populations, the speed of metamorphosis, and, as a consequence, increasing a number of blood meals. In addition, higher temperature increases a speed of virus replication and the reduction of the incubation period within the mosquito midgut and accumulation of the virus in the salivary glands to a sufficient infectious dose [18]. The seasonal activity period determines the number of possible generations of vector species, which is significantly different due to latitudes [19]. It was found that an increase of WNF cases in Europe in 2010 was preceded by abnormal heat [12]. In Volgograd region (Russia), where WNF has been detected annually since 1996, the highest number of cases was also registered in 2010 and in 2012 (413 and 210 cases, respectively), when recorded air temperature was up to $40^{\circ} \mathrm{C}$.

It is interesting to note that the temperature effect on the virus replication is observed only in Culex pipiens $f$. pipiens. Under experimental conditions where mosquitos were kept at $28^{\circ} \mathrm{C}$, the transmission rate increased to $32 \%$ [20]. For the synanthropic subspecies Culex pipiens $f$. molestus transmission rate remained at $10 \%$ and did not change despite the temperature effect [20].

\section{Avian migration}

An introduction of WNV into the new territories occurs along with the seasonal migrations of birds. The migration process generates significant physical stress and immunosuppression and affects the replication of the virus in birds [6]. In addition, during long migrations, there is a large accumulation of migratory species in transitional rest places, which intensifies the transmission cycle and facilitates the pathogen transmission to aboriginal species [21].

One of the most susceptible aves to the WNV are representative of the Corvidae family, among which the rook (Corvus frugilegus L., 1758) is one of the most common species, not only in Ukraine, but also in Europe and Russia. According to the Ukrainian Center for Birds Ringing, a significant part of the rook population winters outside Ukraine, with birds from the northern and central regions wintering mainly in central Europe and birds from the south wintering in southern Europe (Figure 1) [22].

Eastern rooks that naturally breed in Astrakhan region are also known to winter in the territory of Ukraine (Figure 2). Together with the Volgograd and Krasnodar, Astrakhan region are the most well-known endemic territories of WNV in Russia [23,24]. According to visual observation data, birds born in Ukraine have been found in countries with endemic status on WNF [22]. Therefore, every year birds may fly hundreds of kilometers during seasonal migrations and introduce the pathogen from the territories with

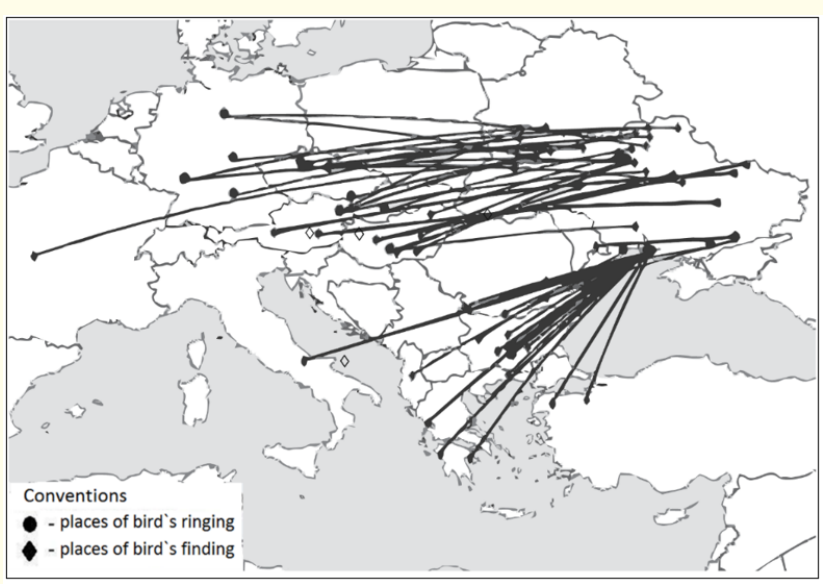

Figure 1: Spatial distribution of Ukrainian rooks during wintering season abroad [22].

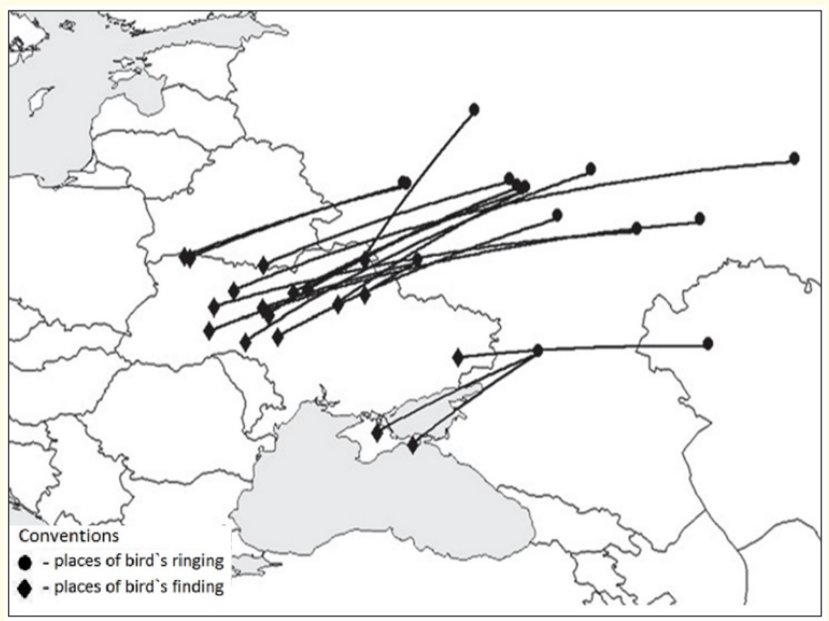

Figure 2: Spatial distribution and flyways of eastern rooks during their seasonal migration [22].

a stable enzootic cycle of WNV to territories were WNV has been never found.

Despite the fact that WNF has been known in Ukraine since 1970s, official statistics were only launched in 2006. To date, 118 cases have been officially recorded in Ukraine (including: 56 cases (1 of which were lethal) in Zaporizhzhia region, 39 in Poltava, 16 in Donetsk, 3 in Mykolayiv and 1 in Zhytomyr, Kharkiv, Kherson and Cherkasy regions). Also, an investigation on seroprevalence in Ukrainian horses revealed a high rate $(13.5 \%)$ of specific antibodies to WNV [2].

The analysis of the geographic distribution and the number of cases of WNF in certain regions of Ukraine suggests a connection 


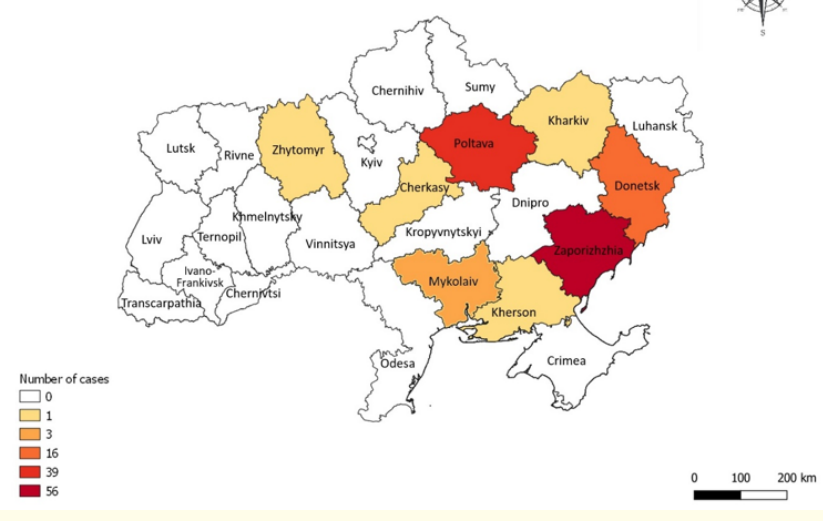

Figure 3: West Nile fever cases among Ukrainian regions.

between the territories with dense human cases (Zaporizhzhya, Donetsk and Mykolaiv regions) and with the Black Sea migration flyway, which connects Volga river delta (Russia) with Danube river delta (Romania) (Figure 3). Since 1996, both territories have been characterized by high rates of human morbidity of WNF [2]. While birds represent a significant mechanisms for WNV dispersal, previous clinical and pathological findings also confirm birds mag succumb to acute neurological disease from infection for WNV lineages with pronounced neuroinvasiveness capability [34].

\section{Phylogenetic relationships}

Based on published reports, the population structure of WNV is classified by five genetic lineages that approximate their geographical isolation $[1,25]$. Lineages associated with prominent outbreaks in humans include lineages 1, 2, and 5 [25-29]. Lineage 1 displays broad geographical distribution and is composed of two clades from distinct geographical regions [30,31]. Clade 1a is comprised of isolates from Africa, Europe, the Middle East, while clade $1 \mathrm{~b}$ is the Australian Kunjin virus (KUNV). Endemic WNV lineage 2 isolates in sub-Saharan Africa and Madagascar and have been associated with sporadic zoonotic outbreaks $[30,32,33]$.

In Europe, WNV lineage 2 strains have been associated with outbreaks in humans and birds [34]. This lineage is believed to have emerged in Africa and subsequently became established in Europe where it has become endemic in multiple regions [35]. To date, limited genome sequences or WNV from Ukraine are available. The genotype of the single avian Ukrainian isolate from 1980 (Genbank accession: JX041631) falls within the Lineage 2 clade and appears intermediate between European isolates and a separate assemblage comprised of two African strains and a single iso- late from Romania (Figure 4). Two WNV genotypes isolates from mosquitoes in the Czech Republic comprise Lineage 3 and have been experimentally shown to infect only mosquito and mosquito cell lines [26,36]. Lineage 4 is represented by isolates present in Russia [23,37] while lineage 5 includes isolates from India and was previously designated clade $1 \mathrm{c}$ within lineage $1[25,27,38]$. More diverse WNV lineages include Koutango virus isolated in Africa as well as a set of isolates from Spain, Malaysia, and a Senegal [29,3941].

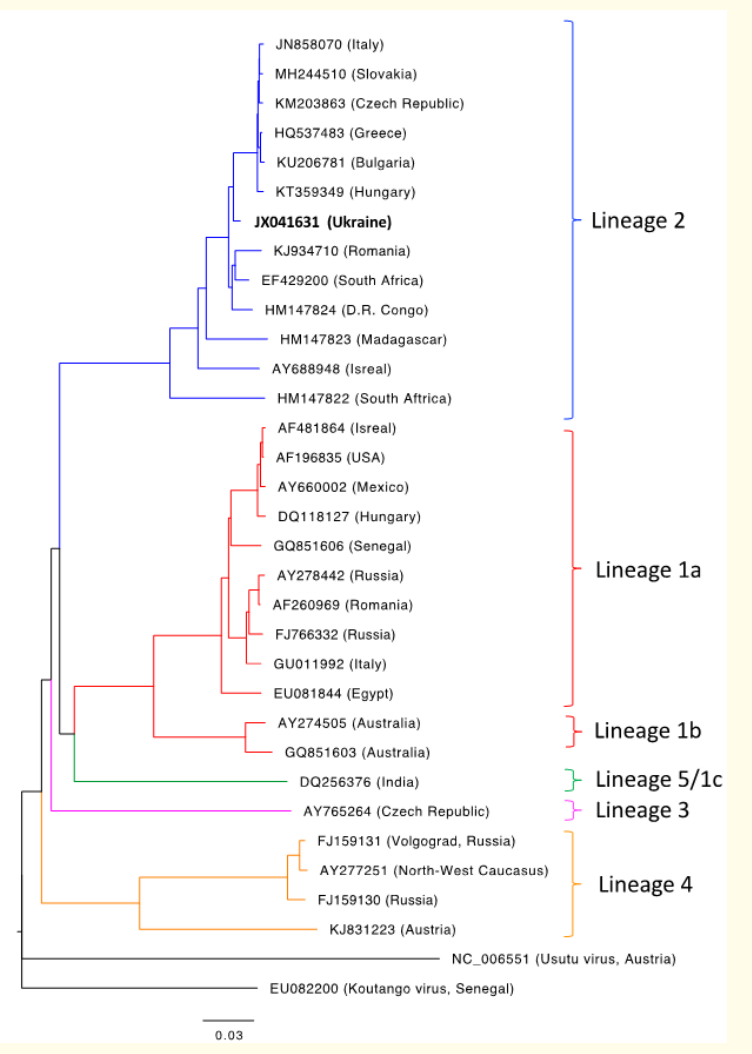

Figure 4: Phylogenetic relationships among global WNV relatives.

\section{Conclusion}

Favorable climatic conditions, water resources and a large number of bird migratory routes create optimal conditions for circulation of the WNV in Ukraine. Rooks that were born in Ukraine and regions with enzootic cycles were also identified in countries with a persistent circulation of the causative agent, including Greece, Bulgaria, Romania, Hungary, the Czech Republic, Austria, France. Such potential transmission links between Ukrainian territories and neighboring European regions where seasonal migrations of WNV-susceptible rooks (Corvus frugilegus) occur, suggest that the introduction of the pathogen to Ukraine occurs from these terri- 
tories via seasonal migratory bird routes. Enhanced viral surveillance and serologic diagnosis of WNF in Ukraine is therefore warranted and remains an essential measure for a clear understanding of the current epidemic situation and the prediction of possible WNV outbreaks in the future.

\section{Acknowledgements}

We sincerely thank Dr. Maureen Long for her kind review of the manuscript.

\section{Bibliography}

1. Chancey C., et al. "The Global Ecology and Epidemiology of West Nile Virus". BioMed Research International (2015): 376230.

2. Ziegler U., et al. "West Nile Virus Antibody Prevalence in Horses of Ukraine". Viruses 5.10 (2013): 2469-82.

3. Sejvar JJ and Marfin AA. "Manifestations of West Nile neuroinvasive disease". Reviews in Medical Virology 16.4 (2006): 209-224.

4. Colpitts, T. M., et al. "West Nile Virus: Biology, Transmission, and Human Infection". Clinical Microbiology Reviews 25.4 (2012): 635-648.

5. Murgue B., et al. "The Ecology and Epidemiology of West Nile Virus in Africa, Europe and Asia". Current Topics in Microbiology and Immunology 267 (2002): 195-221.

6. Tsai TF, et al. "West Nile Encephalitis Epidemic in Southeastern Romania”. Lancet 352.9130 (1998): 767-771.

7. Dinu S., et al. "West Nile Virus Circulation in South-Eastern Romania, 2011 to 2013". Euro Surveillance 20.20 (2015).

8. Paz S and JC Semenza. "Environmental Drivers of West Nile Fever Epidemiology in Europe and Western Asia--a Review”. International Journal of Environmental Research and Public Health 10.8 (2013): 3543-62.

9. Buletsa BA., et al. "[Neurologic Manifestations of West Nile Fever in the Transcarpathian Region]”. Zh Nevropatol Psikhiatr Im S S Korsakova 89.2 (1989): 29-30.

10. Vinograd IA., et al. "[Isolation of West Nile Virus in the Southern Ukraine]”. Voprosy Virusologii 27.5 (1982): 55-57.

11. Semenza JC., et al. "Climate Change Projections of West Nile Virus Infections in Europe: Implications for Blood Safety Practices". Environment Health 15.1 (2016): 28.
12. Paz S and I Albersheim. "Influence of Warming Tendency on Culex Pipiens Population Abundance and on the Probability of West Nile Fever Outbreaks (Israeli Case Study: 2001-2005)”. Ecohealth 5.1 (2008): 40-48.

13. Filatov S. "Little Pigeons Can Carry Great Messages: Potential Distribution and Ecology of Uranotaenia (Pseudoficalbia) Unguiculata Edwards, 1913 (Diptera: Culicidae), a Lesser-Known Mosquito Species from the Western Palaearctic". Parasite and Vectors 10.1 (2017): 464.

14. Gomes B., et al. "Feeding Patterns of Molestus and Pipiens Forms of Culex Pipiens (Diptera: Culicidae) in a Region of High Hybridization". Parasite and Vectors 6 (2013): 93.

15. Mohilevska ZI., "Epidemiological Importance of Sanguivorous Mosquitoes for Arboviral Infections Spreadingon Urban Territories of the South Ukraine" Infectious Diseases (2013) 4.

16. Bertolotti L., et al. "Fine-Scale Genetic Variation and Evolution of West Nile Virus in a Transmission "Hot Spot" in Suburban Chicago, USA". Virology 374.2 (2008): 381-389.

17. Fros JJ., et al. "West Nile Virus: High Transmission Rate in North-Western European Mosquitoes Indicates Its Epidemic Potential and Warrants Increased Surveillance". PLOS Neglected Tropical Diseases 9.7 (2015): e0003956.

18. Becker N., et al. "The Culex Pipiens Complex in Europe". Journal of the American Mosquito Control Association 28.4 (2012): 53-67.

19. Paz S., et al. "Permissive Summer Temperatures of the 2010 European West Nile Fever Upsurge”. PLoS One 8.2 (2013): e56398.

20. Vogels CB., et al. "Vector Competence of Northern European Culex Pipiens Biotypes and Hybrids for West Nile Virus Is Differentially Affected by Temperature". Parasite and Vectors 9.1 (2016): 393.

21. Muzyka DV. "Wild Birds as One of the Main Distribution Factors of Birds, Animals and People Pathogens". Veterinary Medicine 97 (2013): 34-36.

22. Poluda AM and Tsukanova SV. "Characteristics of space-time distribution of the Rook (Corvus frugilesus) related to the territory of Ukraine" Branta: Transactions of the Azov-Black Sea Ornithological Station 15 (2012): 103-120. 
23. Lvov DK., et al. "West Nile virus and other zoonotic viruses in Russia: examples of emerging-reemerging situations". Archives of Virology 18 (2004): 85-96.

24. Monastyrskiy MV., et al. "The Epidemiological Situation of West Nile Fever in Volgograd Region”. Living Systems (2014): 9.

25. Vijay P Bondre., et al. "West Nile virus isolates from India: evidence for a distinct genetic lineage". Journal of General Virology 88.3 (2007): 875-884.

26. Bakonyi T., et al. "Novel Flavivirus or New Lineage of West Nile Virus, Central Europe". Emerging Infectious Diseases 11.2 (2005): 225-231.

27. May FJ., et al. "Phylogeography of West Nile Virus: From the Cradle of Evolution in Africa to Eurasia, Australia, and the Americas". Journal of Virology 85.6 (2011): 2964-2974.

28. Botha EM., et al. "Genetic Determinants of Virulence in Pathogenic Lineage 2 West Nile Virus Strains". Emerging Infectious Diseases 14.2 (2008): 222-230.

29. Vazquez A., et al. "Putative New Lineage of West Nile Virus, Spain”. Emerging Infectious Diseases 16.3 (2010): 549-552.

30. McLean RG., et al. "West Nile Virus in Livestock and Wildlife". Current Topics in Microbiology and Immunology 267 (2002): 271-308.

31. Petersen LR and JT Roehrig. "West Nile Virus: A Reemerging Global Pathogen". Emerging Infectious Diseases 7.4 (2001): 611-614.

32. Lanciotti RS., et al. "Complete Genome Sequences and Phylogenetic Analysis of West Nile Virus Strains Isolated from the United States, Europe, and the Middle East". Virology 298.1 (2002): 96-105.

33. Burt FJ., et al. "Phylogenetic Relationships of Southern African West Nile Virus Isolates". Emerging Infectious Diseases 8.8 (2002): 820-826.

34. Erdelyi K., et al. "Clinical and Pathologic Features of Lineage 2 West Nile Virus Infections in Birds of Prey in Hungary". VectorBorne and Zoonotic Diseases 7.2 (2007): 181-8.

35. Ciccozzi M., et al. "Epidemiological History and Phylogeography of West Nile Virus Lineage 2". Infection, Genetics and Evolution 17 (2013): 46-50.
36. Aliota MT., et al. "Characterization of Rabensburg Virus, a Flavivirus Closely Related to West Nile Virus of the Japanese Encephalitis Antigenic Group”. PLoS One 7.6 (2012): e39387.

37. Platonov AE., et al. "[Genotyping of West Nile Fever Virus Strains Circulating in Southern Russia as an Epidemiological Investigation Method: Principles and Results]". Zhurnal Mikrobiologii, Epidemiologii, i Immunobiologii 2 (2011): 29-37.

38. Chowdhury P., et al. "Characterization of West Nile Virus (Wnv) Isolates from Assam, India: Insights into the Circulating Wnv in Northeastern India". Comparative Immunology, Microbiology and Infectious Diseases 37.1 (2014): 39-47.

39. Scherret JH., et al. "The Relationships between West Nile and Kunjin Viruses". Emerging Infectious Diseases 7.4 (2001): 697 705.

40. Fall G., et al. "Vector Competence of Culex Neavei and Culex Quinquefasciatus (Diptera: Culicidae) from Senegal for Lineages 1, 2, Koutango and a Putative New Lineage of West Nile Virus". The American Journal of Tropical Medicine and Hygiene 90.4 (2014): 747-54.

41. Mackenzie JS and DT Williams. "The Zoonotic Flaviviruses of Southern, South-Eastern and Eastern Asia, and Australasia: The Potential for Emergent Viruses". Zoonoses Public Health 56.6-7 (2009): 338-56.

\section{Assets from publication with us}

- Prompt Acknowledgement after receiving the article

- Thorough Double blinded peer review

- Rapid Publication

- Issue of Publication Certificate

- High visibility of your Published work

Website: https://www.actascientific.com/

Submit Article: https://www.actascientific.com/submission.php Email us: editor@actascientific.com

Contact us: +919182824667 